\title{
Newly undergraduate nurses and intensive care in units of non-critical patients
}

\author{
Enfermeiros recém-formados e o cuidado intensivo em unidades de pacientes não-críticos \\ Enfermeros recién formados y el cuidado intensivo en unidades de pacientes no críticos
}

\section{Rute de Oliveira Almeida' \\ ORCID: 0000-0002-5074-1849}

Francimar Tinoco de Oliveira'

ORCID: 0000-0001-7477-6723

Márcia de Assunção Ferreira' ORCID: 0000-0002-6991-7066

Rafael Celestino da Silva' ORCID: 0000-0002-5211-9586

'Universidade Federal do Rio de Janeiro, Anna Nery Nursing School. Rio de Janeiro, Rio de Janeiro, Brazil.

How to cite this article:

Almeida RO, Oliveira FT, Ferreira MA, Silva RC. Newly undergraduate nurses and intensive care in units of non-critical patients. Rev Bras Enferm [Internet]. 2019;72(Suppl 1):243-51. [Thematic Issue: Work and Management in Nursing]. DOI: http://dx.doi.org/10.1590/0034-7167-2017-0713

\section{Corresponding Author:}

Rafael Celestino da Silva

E-mail: rafaenfer@yahoo.com.br

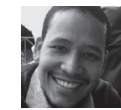

Submission: 08-31-2017

Approval: 06-08-2018

\section{ABSTRACT}

Objective: To identify the social representations of newly undergraduate nurses on the intensive care of Nursing to critical patients hospitalized in non-critical patient units. Method: Qualitative and descriptive research. Twenty-six newly undergraduate nurses from a private university participated. An in-depth interview was conducted with semistructured script. The analysis was of lexical type with the help of Alceste 2012 software. Results: The social representations were built according to the image of the intensive care unit, although patients were out of this environment. Care is understood as complex and specialized, requiring graduate training. Therefore, undergraduation training was considered insufficient to provide this type of care, creating fear and insecurity in the newly undergraduate nurses. Final considerations: Intensive care confronts newly undergraduate nurses with feelings of unpreparedness to care for, but it mobilizes to broaden the knowledge to provide care. There is evidence of a theory-practice dichotomy and weaknesses in teaching-learning experiences in undergraduate education.

Descriptors: Nursing; Intensive Therapy; Professional Practice; Critical Care; Social Psychology.

\section{RESUMO}

Objetivo: Identificar as representações sociais de enfermeiros recém-formados sobre o cuidado intensivo de Enfermagem ao paciente crítico hospitalizado em unidades de pacientes não-críticos. Método: Pesquisa qualitativa e descritiva. Participaram 26 enfermeiros recém-formados de uma universidade privada. Realizou-se entrevista em profundidade com roteiro semiestruturado. A análise foi do tipo lexical com auxílio do software Alceste 2012. Resultados: As representações sociais foram construídas à luz da imagem da unidade de terapia intensiva, apesar de os pacientes estarem fora desse ambiente. $O$ cuidado é compreendido como complexo e especializado, exigindo formação pós-graduada. Portanto, a formação no curso de graduação foi considerada insuficiente para a prestação desse tipo de cuidado, gerando medo e insegurança nos recém-formados. Considerações finais: $O$ cuidado intensivo confronta o recémformado aflorando sentimentos de despreparo para cuidar, mas o mobiliza a ampliar os conhecimentos para exercer o cuidado. Evidencia-se dicotomia teoria-prática e fragilidades nas experiências de ensino-aprendizagem na formação graduada.

Descritores: Enfermagem; Terapia Intensiva; Prática Profissional; Cuidados Críticos; Psicologia Social.

\section{RESUMEN}

Objetivo: Identificar las representaciones sociales de enfermeros recién formados sobre el cuidado intensivo de Enfermería al paciente crítico hospitalizado en unidades de pacientes no críticos. Método: Investigación cualitativa y descriptiva. Participaron 26 enfermeros recién graduados de una universidad privada. Se realizó una entrevista en profundidad con un guión semiestructurado. El análisis fue del tipo léxico con ayuda del software Alceste 2012. Resultados: Las representaciones sociales se construyeron bajo la luz de la imagen de la unidad de terapia intensiva, a pesar de que los pacientes estaban fuera de ese ambiente. El cuidado se entiende como complejo y especializado, exigiendo formación postgraduada. Por lo tanto, la formación en el curso de graduación fue considerada insuficiente para la prestación de ese tipo de cuidado, generando miedo e inseguridad a los recién formados. Consideraciones finales: El cuidado intensivo confronta al recién formado aflorando sentimientos de falta de preparo para cuidar, pero lo moviliza a ampliar los conocimientos para ejercer el cuidado. Se evidencia una dicotomía teoría-práctica y fragilidades en las experiencias de enseñanza-aprendizaje en la formación graduada.

Descriptores: Enfermería; Terapia Intensiva; Práctica Profesional; Cuidados Críticos; Psicología Social. 


\section{INTRODUCTION}

Intensive care is being provided, increasingly more, outside the specialized ICU environment. This affirmation can be supported by the results of research that addressed the difficulties of access to Intensive Care Unit (ICU) beds in the state of Rio de Janeiro from 2010 to 2011, which showed that there were 33,101 medical requests for 268 ICU adjusted beds. The authors concluded that it is necessary to increase the number of ICU beds by $122 \%$ so that the system of vacancy regulation is stable, and by $134 \%$ for a maximum waiting time of six hours ${ }^{(1)}$.

As a result, a significant number of adult patients who cannot vacate the ICU occupy clinical, surgical, diagnostic centers, emergency units, basic health units and households $s^{(2-5)}$, which in this study are understood as hospitalization units of non-critical patients. An example of this presence of critical patients outside the ICU is seen in research on Nursing care for critically ill postoperative patients in the post-anesthetic recovery, which refers to a high demand for critical care for surgical patients and few available beds, resulting in an increase of these patients in the recovery from anesthesia ${ }^{(4)}$.

This assertion is corroborated by research on the challenges for the Nursing team in the emergency care intensive care sector, according to which the insufficiency of vacancies in ICUs brings critical patients in this sector, due to complications of clinical evolution or because they were brought by the Serviço de Atendimento Móvel de Emergência (Emergency Medical Services Ambulance) ${ }^{(5)}$.

In these cases, the transfer to an ICU should be performed as quickly as possible and, in the meantime, patients should be assisted by the team of the unit where they are $\mathrm{in}^{(6)}$. Faced with this current reality, nurses who will provide care to this patient in units of hospitalization of non-critical patients should have as profile: advanced ability of observation; sensitivity to dealing with human frailty; technical and scientific knowledge; and experience to identify and control hemodynamic changes through technology ${ }^{(7)}$.

However, studies on intensive care outside the ICU already indicate limitations in the preparation of full-time nurses in non-critical patient units to assist this clientele. This is the case of research whose focus was to identify the severity and the Nursing workload in patients, candidates to vacancies in the ICU. We verified that the applicant patients who were not admitted to the ICU required a high Nursing workload, with a score very close to the national average of patients who are admitted to the $I C U^{(8)}$.

Considering that, the authors affirm that the units that receive these critical patients outside the ICU may not be prepared in terms of human resources, and qualitative and quantitative aspects, to meet this clientele profile, requiring planning measures to guarantee quality and the safety of Nursing care ${ }^{(8)}$.

A study of the social representations of medical clinic nurses about care of critical patients outside the ICU revealed that the presence of a highly complex patient case in the medical clinic makes the limitations clear in relation to human resources, materials and technical-scientific preparation of professionals $s^{(3)}$.

In this survey, we point out the influence of nurses' experience, since previous experiences affect how the patient acts in the face of critical patient care, that is, the longer the nurse's working time, the greater the knowledge and the skills to act ${ }^{(9)}$.
However, recent undergraduates are the most recruited human resources ${ }^{(10)}$, which results in their contact with this clientele in inpatient units of non-critical patients.

Newly undergraduates are considered newcomers in a field of activity, that is, they do not have experience and/or mastery of care, even if they have experience in another area ${ }^{(9)}$. Although there is little global evidence on the qualification of these newly trained to provide intensive care for the first time ${ }^{(11)}$, surveys describing their characteristics at the interface with intensive care point to limitations in clinical decision making and difficulties in caring for safety, mainly by the dichotomy of the theory with the reality experienced in the field ${ }^{(12-13)}$.

It is assumed that the inexperience and unpreparedness of newly undergraduates for the critical patient in non-critical units brings to light an imaginary involving this intensive care, which is classified as complex, challenging, admired or feared. This imaginary mobilizes affections and information in this group, which give meanings to the intensive care and end up affecting the ways of acting that are established from them. Therefore, they are products of social representations and can have repercussions on patient safety.

\section{OBJECTIVE}

To identify the social representations (SR) of newly undergraduate nurses on the intensive care of Nursing to critical patients hospitalized in non-critical patient units.

\section{METHOD}

\section{Ethical aspects}

This project was approved by the Research Ethics Committee of the Escola de Enfermagem Anna Nery/Hospital Escola São Francisco de Assis - HESFA. The participants signed the Informed Consent Term. Participants are identified numerically (ind1, ind2...), and the excerpts follow the software code applied in the analysis.

\section{Type of study and theoretical framework}

Field research of descriptive character, qualitative approach and application of SR theory in the procedural aspect. In SR there is a diversity of concepts and phenomena that mobilize interest and demand understanding. Such concepts have an immediate relevance in people's lives or an important currentness that interferes with their daily lives. From this interest, individuals collectively elaborate common-sense theories to interpret such reality, which guide the way in which they produce and justify behaviors and interactions with the phenomenon ${ }^{(14)}$.

In the context of present research, critical patient presence in non-critical patient units is often problematized in the mass media, which produces a media discourse on intensive care, particularly on the availability of beds for critical patients and the consequent need for their stay in other units. This results in a pressure on inference ${ }^{(14)}$ about this care, considering the impacts that it brings to professionals that provide care, becoming part of the contents of their daily debates as a relevant subject and 
leading this group to produce knowledge that influences the actions in care. Thus, SR as reference allows us to understand such thoughts and actions.

\section{Methodological procedures}

\section{Field}

The field was a private university institution located in the city of Rio de Janeiro. The Nursing course is offered in the morning and the evening, in ten academic semesters or five years, totaling 4,080 hours of workload. The theoretical discipline of Nursing in ICU is offered in the sixth semester and the Curricular Internship in the tenth, in public and private hospitals. Most Nursing students at this institution attend the course in the evening, because they are inserted in the job market with paid occupation, either in the Health area or in another, which hinders the option to attend classes in the morning.

\section{Data sources}

The study participants were newly undergraduated in Nursing, who met the criterion of inclusion: to have completed the undergraduate course in the period defined to produce data. Those who had previous course of auxiliary or Nursing technician were excluded.

This criterion was adopted because in SR the previous experiences of contact with the phenomenon are focused on its elaboration $^{(14)}$. In this sense, as in the category of Nursing technician there was the possibility of having dealt, professionally, with intensive care in the field of Nursing care, influencing the construction of $\mathrm{SR}$, we decided to exclude this group.

Other characteristics of participants related to their training, such as: previous courses; extracurricular internship; performance/ training in another area; were not considered a priori exclusion criteria for participants, but were object of later analysis as to its association with the discursive production.

The possible number of participants was 40 newly undergraduates per semester. After the ethical approval of the project, the researcher immersed herself in the practical fields of the Curricular Internship in ICU course, which is developed in the last semester, accompanying the students in the activities of the internship. This was a stage of approach to potential participants, in which students were approached individually to explain the study, to select those that met the inclusion criterion and capture the contacts. The researcher had no prior professional contact with such students.

Immediately upon completing the course, the researcher would make individual contact with those who had been previously selected, inviting them to the study and scheduling the production of data. It is noteworthy that the formal recruitment of participants of the study occurred only after the students' undergraduation completion, for two reasons: the inclusion criterion requires newly undergraduate nurses; with the participants already undergraduated we could avoid conflicts of interest, therefore, there would be no relation between participating in the study and being a student.
Thus, at the time of data production participants were still entering the job market as nurses. In the academic semester 2016.1 39 nurses were undergraduated and in 2016.2, 62, including 12 and 14 , of each period, respectively.

\section{Collection, organization and analysis of data}

Those who accepted and signed the Term of Free and Informed Consent participated in the in-depth interview, held in a room in the institution that hosted the study, which lasted between 20 and 30 minutes. The interview was based on an instrument containing two parts: the first with objective questions to capture sociodemographic data, with the purpose of describing the profile of the subjects and characterizing the group's feeling of belonging.

This information is important to understand SR, from the context in which the participants are inserted. In this sense, the data was collected on the area chosen to work, extracurricular internship, other training, courses/events on intensive care and experience in another area. We sought to articulate these characteristics with the narrative about the object.

The second part of the instrument consisted of fourteen semi-structured questions that explored the SR dimensions of the newly undergraduates on intensive care units in non-critical patients. Thus, the questions referred to undergraduate training in intensive care, conceptions of the newly undergraduated on intensive care outside the ICU, their performance in relation to this care outside the ICU, professional requirements for this practice, difficulties faced, and risks to patient's safety regarding intensive care outside the ICU. The data was recorded in a digital device and later transcribed.

At the end of each semester, we sought to capture the maximum possible number of participants to conduct the interviews. However, since many were excluded due to previous training as Nursing technicians, only 26 interviews were conducted, which was the total number of participants that met the inclusion criteria and agreed to participate.

Thus, the researcher made an analysis of the density of this data in the clarification of the phenomenon of study and in the achievement of the objectives in the interface with the theoretical framework. In this pre-analysis, it was found that such data was enough to meet the internal validity principle of research, and it was not necessary to extend the data production period to an additional academic semester, since it was clear that it had reached empirical saturation ${ }^{(15)}$.

The interviews were carried out from July 2016 to January 2017. After transcribing the interviews, the corpus was prepared according to the standards of the software Analyse Lexical par Contexted un Ensemble de Segments de Texte (ALCESTE), 2012 version.

The Alceste program processed the analysis of participants' discourses due to the similarity and non-statistical similarity of the words produced by them and which compose the corpus of textual data(16). Thus, the analysis brought to light the lexical worlds conveyed by participants, which provided rationality to their discourse.

Among the analysis parameters generated by the program, the focus of this article is the descending hierarchical classification (DHC). The program counted words in the text, grouped its semantic 
roots and defined lexical classes according to the occurrence and co-occurrence of these words and their textual function. For the extraction of classes, the software Alceste divided the text into discursive fragments called units of elementary contexts (UEC), with exploration of the lexicons present in these UEC.

In this way, the crossing of the reduced forms of words in the UEC generated classes of UEC with similar vocabulary each other but different from other classes. In the analysis of DHC, it is possible to apprehend the relations between classes, of opposition and similarity, from the distribution of their vocabulary. This analysis is made considering the lexicons of greatest association to the class; the measurement by $\mathrm{Phi}^{2}$ and its presence in the UEC; the characteristic words of the class evaluated by the percentage value; and the profile variables that were highlighted in the class organization.

\section{RESULTS}

The profile of participants regarding personal data is: $85 \%$ female; $80 \%$ single; $73 \%$ being 20 to 30 years. Regarding professional characteristics: $23 \%$ chose to work in the ICU; $27 \%$ attended extracurricular internships; and 38\% participated in intensive care courses or events; $69 \%$ do not work in another area currently; and $77 \%$ have no other training.

In the corpus of 26 interviews submitted to the analysis, we obtained 2,841 different words, with 33,707 occurrences. The corpus was divided into 783 UEC, and into two hierarchical descendant classifications, subdivided into two class blocks, with a total of 6 lexical classes and $68 \%$ of use. For this article, the focus will be the analytical deepening of the block that is structured around classes 2, 3 and 4 .

Class 2 was formed by 67 UEC, corresponding to $13 \%$ of the corpus. In this class, the discourse about nurses' training during their undergraduation on intensive care prevailed, which involves theory, practice and teacher. The lexicon "like" (like/liked) is evaluative and has a high $\mathrm{Phi}^{2}$ in this class. Thus, next to the words 'internship' and 'field' it refers to an evaluation of practical classes, while when articulated to the words 'classroom' and 'room' it refers to the theoretical classes, which were also related to the lexicon 'professor':

Well, I think the theoretical part was very good with the teacher we had, he explains with his day-to-day examples and everything, and so, the theoretical part I think was very good, but in the practical part, the internship[...]. (UEC No. 54, ind. 02)

But I even liked it, I found it interesting. About this area, I could even work with it, because I changed my perspective, I saw that it was not rocket science, it was not so difficult. As for the theoretical subject, we did not learn much, at least it's my opinion, it was a bit deficient in this part. But at the internship, no, the teacher answered all our questions, taught everything, was very efficient. (UEC no. 212, ind. 07)

\begin{tabular}{|c|c|c|c|c|c|c|c|c|c|c|c|c|c|c|c|c|c|}
\hline & & & & & & & $\begin{array}{l}01 \text { 1è } \\
2\end{array}$ & $\begin{array}{l}\text { ère } c \\
\text { ème }\end{array}$ & $\begin{array}{l}\text { sification } \\
\text { assification }\end{array}$ & & & & & & & & \\
\hline Class & & & Clas & & & Clas & & & & & & & & & & & \\
\hline & & & & & ste de & nots sgnificati & de chaq & que cl & se avec leur & ient $d^{\prime}$ & 'associ & ion Phi & & & & & \\
\hline Forme & Phi & Eff. & Forme & Phi & Eff. & Forme & Phi & Eff. & Forme & Phi & Eff. & Forme & Phi & Eff. & Forme & Phi & Eff. \\
\hline tentar & 0,27 & 33 & error & 0,37 & 20 & profission & 0,30 & 27 & ano & 0,29 & 21 & pront & 0,29 & 8 & estagio & 0,48 & 43 \\
\hline iria & 0,26 & 16 & risco & 0,32 & 21 & quest & 0,24 & 26 & tecn & 0,27 & 42 & segur & 0,29 & 6 & professor & 0,40 & 25 \\
\hline monitoriz & 0,24 & 10 & infecc & 0,27 & 8 & setor & 0,23 & 23 & sai & 0,22 & 11 & qualific & 0,29 & 6 & aula & 0,37 & 14 \\
\hline paciente & 0,23 & 100 & pod & 0,26 & 38 & complexid & 0,22 & 6 & ajud & 0,20 & 19 & pos_gradu & 0,29 & 6 & gost & 0,35 & 23 \\
\hline dar & 0,22 & 21 & segurança & 0,24 & 14 & coloc & 0,21 & 15 & pens & 0,20 & 22 & estud & 0,24 & 10 & teve & 0,34 & 16 \\
\hline melhor & 0,21 & 18 & caus & 0,21 & 6 & ness & 0,21 & 11 & aprend & 0,20 & 21 & curso & 0,24 & 6 & conteudo & 0,30 & 9 \\
\hline sej & 0,20 & 14 & pior & 0,21 & 5 & as & 0,19 & 38 & faculdade & 0,20 & 22 & meses & 0,22 & 4 & cont & 0,28 & 15 \\
\hline sozinha & 0,19 & 7 & fazendo & 0,22 & 14 & equip & 0,19 & 25 & sei & 0,19 & 40 & experienci & 0,22 & 18 & campo & 0,28 & 8 \\
\hline aparelho & 0,19 & 8 & acesso & 0,19 & 8 & unidade_d & 0,18 & 45 & gente & 0,19 & 100 & principalm & 0,20 & 5 & curricular & 0,28 & 6 \\
\hline atendimento & 0,19 & 9 & aumento & 0,19 & 4 & do & 0,16 & 46 & vem & 0,19 & 6 & sent & 0,20 & 7 & procedime & 0,27 & 15 \\
\hline tratamento & 0,18 & 7 & acredit & 0,17 & 22 & meio & 0,16 & 9 & mostr & 0,19 & 9 & residencia & 0,18 & 4 & aluno & 0,22 & 4 \\
\hline agir & 0,17 & 6 & equipamento & 0,17 & 7 & grande & 0,16 & 8 & cheg & 0,17 & 27 & busc & 0,17 & 9 & sala & 0,21 & 9 \\
\hline vaga & 0,17 & 8 & responsab & 0,17 & 9 & dificil & 0,16 & 16 & pergunt & 0,18 & 9 & treinamen & 0,17 & 9 & fiz & 0,21 & 6 \\
\hline corre & 0,17 & 11 & dess & 0,16 & 11 & atend & 0,16 & 5 & nisso & 0,17 & 5 & cas & 0,17 & 5 & teor & 0,21 & 13 \\
\hline clinica_medica & 0,18 & 15 & tipo & 0,16 & 8 & grupo & 0,16 & 3 & diploma & 0,17 & 5 & cham & 0,16 & 3 & tir & 0,20 & 5 \\
\hline grave & 0,17 & 7 & usar & 0,16 & 4 & intensiv & 0,16 & 5 & opiniao & 0,17 & 6 & trein & 0,15 & 2 & duvida & 0,19 & 6 \\
\hline precis & 0,17 & 27 & droga & 0,15 & 6 & alta & 0,15 & 4 & depar & 0,16 & 6 & vontade & 0,15 & 2 & positiv & 0,19 & 3 \\
\hline poss & 0,17 & 22 & paciente & 0,16 & 42 & manej & 0,15 & 4 & sab & 0,15 & 41 & recem_fo & 0,15 & 6 & oportunida & 0,19 & 8 \\
\hline adequ & 0,16 & 10 & gravidade & 0,15 & 3 & desafio & 0,15 & 6 & igual & 0,15 & 4 & comec & 0,14 & 4 & hospital_n & 0,19 & 3 \\
\hline tivesse & 0,16 & 11 & prest & 0,15 & 12 & mundo & 0,13 & 5 & consegu & 0,16 & 28 & enfermeiro & 0,14 & 10 & pud & 0,18 & 7 \\
\hline enfermaria & 0,16 & 13 & prepar & 0,15 & 7 & recurso & 0,13 & 7 & vida & 0,15 & 19 & desej & 0,13 & 2 & gente & 0,17 & 31 \\
\hline monitoramento & 0,16 & 4 & ambient & 0,15 & 11 & acompanh & 0,13 & 5 & situac & 0,15 & 13 & instituic & 0,13 & 3 & ir & 0,17 & 4 \\
\hline foss & 0,15 & 7 & dependenc & 0,15 & 7 & uma & 0,13 & 67 & cru & 0,14 & 5 & extracurric & 0,13 & 2 & bas & 0,17 & 11 \\
\hline maximo & 0,15 & 7 & med & 0,14 & 14 & numer & 0,13 & 3 & fez & 0,14 & 5 & falt & 0,11 & 7 & part & 0,17 & 12 \\
\hline monitor & 0,15 & 6 & rece & 0,14 & 5 & assistir & 0,13 & 3 & sair & 0,14 & 7 & especializ & 0,11 & 5 & observ & 0,17 & 4 \\
\hline emergencia & 0,15 & 11 & poder & 0,14 & 12 & enfermagem & 0,12 & 5 & querendo & 0,14 & 6 & dig & 0,10 & 4 & interess & 0,17 & 4 \\
\hline bomba & 0,14 & 3 & prejudic & 0,14 & 4 & dimension & 0,13 & 4 & lid & 0,13 & 15 & vou & 0,11 & 10 & bon & 0,16 & 4 \\
\hline Variable & Phi & Eff. & Variable & Phi & Eff. & Variable & Phi & Eff. & Variable & Phi & Eff. & Variable & Phi & Eff. & Variable & Phi & Eff. \\
\hline *ind_21 & 0,11 & 8 & *ind_09 & 0,22 & 10 & *ind_24 & 0,33 & 24 & *ind_11 & 0,24 & 27 & *ind_25 & 0,11 & 7 & *ind_01 & 0,12 & 10 \\
\hline *esc_1 & 0,10 & 49 & *ind_22 & 0,14 & 5 & *ind_14 & 0,18 & 6 & *qual_1 & 0,18 & 85 & *ind_20 & 0,10 & 4 & *ind_07 & 0,12 & 4 \\
\hline *ida_2 & 0,10 & 35 & *ind_02 & 0,13 & 9 & *qual_2 & 0,17 & 63 & *ind_06 & 0,12 & 11 & *ind_17 & 0,09 & 3 & *ind_03 & 0,12 & 5 \\
\hline *ind_03 & 0,08 & 12 & *ind_20 & 0,12 & 6 & *ind_04 & 0,11 & 5 & *ind_18 & 0,12 & 17 & *ind_16 & 0,08 & 3 & *ind_12 & 0,10 & 4 \\
\hline
\end{tabular}

Source - Alceste Report, 2017

Figure 1 - Dendogram of descending hierarchical classification 
One of the elements that sustains this evaluation of participants about their training are the opportunities to perform procedures, which are directly related to the practical field. The lexical'procedure' and 'opportunity' express the evaluation of participants about their practical experience during undergraduation, based on the opportunities they had to perform the procedural techniques in internships.

I managed to do the procedures and when I had questions, I got answers. Yes, it was positive. (UEC no. 5, ind. 01)

It is an area that really calls my attention, emergency and now ICU. I started to like it exactly during my internship period, where I was able to do procedures, for example, set up equipment to measure mean blood pressure, assist doctors in the procedure, make a bandage, because all this is new for me. (UEC no. 590, ind. 21)

Opportunities for performing the procedures were more positive or negative in relation to the assessment of critical care training, according to which each participant had access during the internship, expressed in lexical 'had', 'field' and 'curricular'.

I think I have nothing to complain about, I thought it was good, I was able to approach the contents, my questions were all answered, also during internships, I managed to do the procedures, the teacher was there. (UEC no. 9, ind. 01)

Actually, I already liked the intensive care unit in theoretical classes and when I went to the mandatory curricular internship of the university I liked it because of the procedures we can do, have access. (UEC no. 1, ind. 01)

On the other hand, the negative evaluation arises when the participant realized that he/she did not have enough opportunities to perform the procedures, regarding contact with patients:

In relation to critical patients, I found myself weak, very weak, the professors were excellent, they had a lot of knowledge, they answered all the questions I made, but it was not because I had many students, it was because I did not have many procedures. (UEC no. 280, ind. 10)

They would do procedures beforehand and say: "I already did the procedure!"I would observe more than practice something. At university, they give a basis, but I think it's a very complex part in which you must dive deep, you have to study a lot, I think so, dedicate yourself to the maximum because it's a difficult sector. (UEC no. 52, ind. 02)

The UEC show the separation of theoretical and practical teaching (classroom and internship subjects), occurring at different times of training at the researched university, within almost two years and with different professors and settings of practice.

There is a distance between theory and practice, which becomes a difficulty. I really enjoyed studying here, I think I had a good training, a good foundation, professors are good, they have a good interaction, they explain well, they are good.(UEC no. 408, ind. 13)

Class 3 was composed of 126 UEC, equivalent to $25 \%$ of the corpus, and portrays how the newly undergraduate nurse feels about leaving university in front of the job market. Lexicon:'year', 'five,' 'university' and 'learn' refer to an analysis of what the newly trained nurse learned during the five years of undergraduation.

This analysis is performed when nurses reflect on their performance in the care of critical patients outside the ICU, concluding that, given the five-year training time and, mainly, the time of one semester in a practical field in the ICU, little is known about it and they are unprepared.

There's also a lack of knowledge, I could not learn everything during university, we have five years of classes, but if we stop to think we have almost three months only, because then comes adaptation. (UEC no. 190, ind. 06)

I don't know if I could answer you, but it's complicated, it's rocket science for the people who are finishing university now, there are people who say: No, we can handle it! You have five years to become and undergraduate, and then a countdown: four, three, two years. (UEC no. 370, ind. 11)

There are a lot of things that we don't learn during university, unfortunately, but I don't think it's the university itself; in my opinion, a year of internship is not enough, for an undergraduate it is not enough, in my opinion.(UEC no. 265, ind. 09)

In this evaluation of how newly undergraduate nurses feel about their training and insertion in the job market, the unpreparedness to act using the 'raw metaphor' is detected. The image of the unprepared professional is constructed with the articulation of the lexicons: 'raw', 'leave' and 'feeling'.

I think we leave university really raw, not only in relation to the intensive care unit, but compared to other clinics too, it's very difficult. (UEC no. 152, ind. 04)

And how will I handle that? I don't know what to answer, because I don't know this answer either, and I don't know what is my, because I'm raw too, and in this situation I would also freak out, I don't know, when you stop to think, you put up a different point of view. (UEC no. 367, ind. 11)

This evaluation that they are leaving university raw is based on the previous experiences they had, as evidenced by the use of the technical lexicon. This lexicon appears in this class, indicating the understanding that new undergraduates who have previous training as a Nursing technician have less difficulties and are more confident in their work as nurses, unlike the raw ones, where lack of confidence is a mark present in speeches.

They already worked in the intensive care unit, even as a technician, they ended up knowing and learning other things, but those who are not technicians have the same fear I do. (UEC no. 190, ind. 06)

Well, I believe so, because those who are already a technician have an idea about what the hospital is like. I do not have any, I feel very insecure about getting a job, because in my head I don't know a thing. (UEC no. 558, ind. 19)

The analysis of newly undergraduate nurses that teachinglearning experiences were insufficient to properly prepare them 
for the job market culminates in the conclusion that they leave university raw. Faced with the situations they will see in the job market, they are afraid and worried if they will meet expectations and play their role as nurses. The lexicon 'think','can do' and 'learn' portray this idea.

I know that one day l'll learn, but that it may someone's life, it worries me a lot. I'm also worried about how people are going to look at me inside a hospital: "she does not know anything"; and I've heard that technicians are mean to nurses who know nothing, that they tease us a little, these things worry me. (UEC no. 199 , ind. 06)

It is terrifying to get a job right after undergraduation. I believe that some think just like me, others are desperate to work, so they should not think too much about it when it comes to accepting a position, they must accept and that's it. (UEC no. 558, ind. 10)

That's so true that sometimes / wonder if I really chose the right profession, I fear not being able to care for patients. A bleeding control, I think one, yes, I think a bleeding, a cardiac arrest, we learned at university, but I don't know how it would live, but I think my biggest fear would be a limb amputated in an accident. (UEC no. 185, ind. 06)

Made of $44 \%$ UEC and accounting for $8 \%$ of the total data corpus, the words that identify class 4 deal fundamentally with the different strategies that the newly undergraduate nurses intend to use to deal with intensive care to critical patients. In this way, the these nurses declare that they are not ready, evidenced by the use of lexicons:'ready', 'secure,' 'experience' and 'feel', as follows:

One hundred percent, not one hundred percent, not yet, but I still feel very insecure. Even this contact, having more this experience, the experience. (UEC no. 653, ind. 23)

No, I'm not ready like I said, it would take two to three months of work so I could feel confidents to act alone, it would be a training. (UEC no. 494, ind. 17)

"You're going to work here, you start tomorrow"... I've never entered there in my life, how can I do it? Although I want to, I'm not ready, I intend to go into residency. (UEC no. 752, ind. 25)

To overcome the difficulties, the newly undergraduates communicate strategies to acquire self-confidence and security for critical patient care. The lexicons 'search' and 'lexical' shown in the UEC exemplify their pretensions to overcome the lack of experience:

But it does not always happen, they usually ask for experience in intensive care unit, yes, they do. But I think you must seek specialization, first in the clinical area, urgency and emergency, and then seek specialization, a graduation. (UEC no. 583, ind. 20)

Considering the representation that they have little training to act, participants dictate strategies to acquire knowledge: one, through the lato sensu specialization in ICU; the other, through Nursing Residency, which would give them practical experience, since the supervised condition would contribute to develop selfconfidence in critical patient care.
I need to have more experience to feel secure, and I think I will achieve this with a specialization and practice to develop experience, and I will only achieve this with practice, so I would go with fear, but I would. (UEC no. 588, ind. 20)

Enter residency, a graduation, study at home, this kind of things. (UEC no. 755 , ind. 25)

Another type of strategy mentioned is the search for knowledge through individual initiatives, qualification courses, as well as through help of more experienced and trained nurses during the execution of procedures.

We must also study, seek to learn, not only in training, but out by ourselves, courses, in short, get some knowledge and dedicate to training, do everything right, clarify any questions you may have, make questions. (UEC no. 91, ind. 02)

I will join the people who really know that they can teach me, and if I cannot, have an experience like a graduation in an intensive care unit, or even specialization, residency. (UEC no. 359, ind. 11)

The desire expresses the protagonism of professionals in the choice of the sector of performance; however, newly trained nurses recognize that they can be called to act in the ICU and, in this sense, the triad desire, need and professional duty emerges as an ethical imperative and demands proper technical training for the specific care required.

The nurse is key element, I think the person has to locate herself/ himself. Look, ready, ready, I don't think so. But I think I should do more, have desire to be there and if I'm called to work in an intensive care unit I go, but based on that principle that I'm going to study, I'll want to be there. (UEC no. 708, ind. 24)

\section{DISCUSSION}

SR are designed to interpret reality, but also to act in relation to reality, assuming a prescriptive role as a guide to actions. Therefore, SR become reality for social actors ${ }^{(14)}$. The way in which the new undergraduates construct meanings for the intensive care outside the ICU and organize their actions before them is evidenced in the results based on the evaluation of specific training directed to intensive care; in the evaluation of Nursing undergraduate training as for the job market; and strategies to target the best training for intensive care.

The connections of these senses allow us to affirm that the phenomenon/object is thought by the newly nurses from their natural context, that in the case of intensive care is the ICU. This time, even participants who were taken to reflect on intensive care outside the ICU, think about it from the ICU, which is expressed in their speeches when they refer to this setting.

In the process of definition of SR, the context of ICU brings the imaginary dimension that gives meaning to the phenomenon. SR are designed to respond to the new and exotic social phenomena with which people have contact in the contemporary world, from the incorporation of the scientific repertoire to their daily lives. For this, people use images to provide concreteness to something initially abstract, giving it meaning in a process called objectification ${ }^{(14)}$. 
Therefore, intensive care in the ICU is characterized by participants as procedural (biomedical), specialized (place of experienced people) and complex, being objectified in the image of a "rocket science".

Intensive care, when located outside the ICU, brings with it its image and characteristics, bringing out some affection in the new ones. The affections encompass processes that turn to social belonging and individual potentiality. This is because the exchanges between individuals and between subject/society, while feeding the social system, also keep alive the individualities of each. Thus, when something threatens to disintegrate the social group, it has effects on the integration of the self. The construction of social representations is part of a psychosocial commitment to safeguard the balance between the members of the group, which contributes to organize the thinking of each subject ${ }^{(17)}$.

Therefore, affections arise related to the need to remove the threat of disintegration of the self and to preserve the identifications of the social group, and social representations as a form of knowledge enable this movement ${ }^{(17)}$. Since the training of the newly undergraduate nurses is generalist, providing intensive care (considered specialized) in a unit of non-critical patients, outlines their fragilities, constituting both a threat to themselves as to the other (group) and feelings of fear and insecurity mobilize them to put up a representation which preserves the features of this social group, that is, being newly undergraduates.

This affective mobilization results in the evaluation of training directed to intensive care, which has a positive or negative liking/ not liking, located in the technical procedures performed during the internship, as well as in the time gap between theoretical and practical classes. Given the assessment that there are limitations in academic training, according to the interviewees, newly trained nurses express themselves through the raw metaphor to refer to their condition of not being prepared for the job market, which is associated with the feeling of inexperience in relation to care, especially when they think about intensive care, as a way of justifying the difficulties in their performance in front of them.

The evaluation of training in counterpoint to the demands of care activities in the field of work is discussed in some studies. One of them, which aimed to characterize the training of Nursing professionals and the adequacy of this training to the work activity, showed that half of the nurses consider that their training did not meet the needs of their work activity. In conclusion, studies pointed out that in addition to academic training, most Nursing professionals interviewed affirmed that they had taken continuing education courses or participated in conferences, conventions, training seminars, but that these events were not appropriate to perform their professional roles ${ }^{(18)}$.

More specifically, as for training related to intensive care, in a study that sought to analyze the limits and possibilities inherent in the academic and professional training of nurses working in the ICU of hospitals in a state of Brazil, it was found that a large number of nurses interviewed did not have in their curriculum the discipline of Intensive Care and the mandatory internships in ICU. Consequently, many of them affirmed that they faced difficulties in the beginning of their careers to work in ICU, due to academic (lack of) training. The result pointed to a predominance of nurses working in ICU who were not included in the discipline of Intensive Care in Nursing undergraduate academic curriculum ${ }^{(19)}$.
This data is corroborated by a second investigation, which described the profile of nurses working in two ICUs of a teaching hospital. The profile showed that some professionals had basic academic preparation, with minimum working hours and little practice in ICU, which made it difficult for them to enter their professional lives, especially when the first contact was intensive care. We concluded that, because of their limitations, these professionals need to develop skills to provide safe care ${ }^{(12)}$.

Considering these deficiencies in training, national and international studies debate the transition from student to professional status, bringing the experience of the newly undergraduate nurses, marked by feelings of fear and unpreparedness, mainly regarding technical skills ${ }^{(20-22)}$.

An example of this is the one that sought to understand how these nurses experience their first job. The study states that the world of work for newly trained nurses may represent a stressful situation, because they are, simultaneously, eager to start their professional activities and fearful of the unknown. Some factors may act as facilitators in the transition from academic life to work life, such as academic education with good theoretical foundation, extracurricular internships, institutional posture to stimulate educational development and support of the Nursing team ${ }^{(20)}$.

In research that deals with this transition by relating it to intensive care, these characteristics are also present. The lack of experience of the recent graduates as for clinical skills was addressed in a study carried out, to know the perception of experienced nurses about recent undergraduates who are working in ICU. Two themes were extracted from the results of research: the lack of confidence of these newly trained nurses to develop their roles and the need to gain acceptance in the culture of the unit ${ }^{(21)}$.

Lack of trust was attributed to problems of inexperience of these nurses, fear, and inability to think critically. Newly trained nurses often have difficulty setting priorities and managing time. These aspects contribute to increase the lack of confidence, which can paralyse them. The second point was the importance of welcoming and accepting the newly undergraduated in the work sector. Disregard for the work of newly trained nurses, ignorance or refusal to answer a question, can diminish any confidence, overwhelm them, and reduce commitment to the unit ${ }^{(21)}$.

A phenomenological study about the experience of 10 new nurses in an ICU showed that the interpersonal relations experienced by them gave rise to diverse thoughts, perceptions and feelings that may have an impact on their development and job satisfaction. In this study, recent undergraduates tried to hide their level of inexperience in ICU of from patients and their families, avoiding answering the question about their experience time and saying their age or hiding their physical appearance $^{(22)}$

In the results of research presented here, SR constructed based on the ICU image imply a level of qualification of care in which the training in undergraduate education is not enough to meet. This is evidenced in the speeches of the newly undergraduates, who use the ready ('not ready') lexicon for the intensive care of patients. Thus, to overcome the difficulties and feel more secure during care, participants point out in their statements that the specialization in ICU and in residency are the strategies to be 
adopted to acquire the appropriate qualification to provide care for critical patients.

These strategies were also present in a study that aimed to analyze the contribution of the process of critical-creative training in the insertion of nurses in the labor market and evidenced the search for professional qualification through specializations in professional performance, and through strict sensu graduation courses $^{(23)}$.

The findings of this study with resident nurses of two programs in Rio de Janeiro, on the motivations and expectations of the option for the specialization course in Nursing in residency revealed that nurses opt for this type of course for the opportunities to acquire more practical experiences, attending to their perceived needs for the acquisition of professional skills. Residents expect to acquire knowledge and skills to work with confidence in their profession ${ }^{(24)}$.

In Finland, research on the competence of newly trained nurses specializing in Critical Care Nursing showed good selfassessment, with nurses relying on their basic knowledge, but the results of the basic knowledge test were not satisfactory ${ }^{(25)}$. Therefore, we see that self-confidence does not always reflect good training and vice versa, and there is a need for investments in both aspects of vocational training.

\section{Study limitations}

Study limitations are related to our methodological choices, in view of the exclusion criterion - previous training as a Nursing technician - associated to the profile of students of the University chosen for research, which restricted the number of participants, limiting the scope of the results. In addition, since data production occurred after the conclusion of the undergraduate course, there were difficulties to contact some participants previously selected to participate in research, as well as to have the acceptance of some of them in returning to the training institution to produce data, which also limited the number of participants.

\section{Contributions to the nursing, health or public policy sectors}

The social representations identified point to the need for their re-signification in undergraduate training for intensive care, so that future professionals are sensitized about the importance of their minimum training to attend this care demand with confidence, regardless of the specialization and area of choice. For that, we must intervene on aspects of curricular and pedagogical structure: the time lapse between theory and practice, the shock with the practical reality without time for adaptation, fields without effective learning experiences, options of better conditions of market insertion of newly undergraduates regarding the possibility of critical patient care in wards, and reduction of fear and insecurity.

\section{FINAL CONSIDERATIONS}

The social representations of newly undergraduates on intensive care in non-critical patient units are constructed based on the ICU's image and the care they perform in this field: complex and specialized. Therefore, to exercise it safely, undergraduate training is not considered enough, making it necessary to enter a graduation course. Nevertheless, this type of hospitalized patients outside the specialized field, increasingly common in health institutions, confronts the newly undergraduate nurses and there are feelings of unpreparedness for care. These feelings generate fear and lack of confidence in these professionals, who react in a positive way, suggesting the improvement of their technical and scientific knowledge through specialization and graduation courses.

SR of newly undergraduate nurses reveal situations related to undergraduate education, with a theory-practice dichotomy and weaknesses in teaching-learning experiences, which do not meet the new demands of intensive care when it is performed outside ICU. We must discuss the generalist education, which must guarantee learning experiences so that nurses can safely attend critical patients, even if they are outside ICU.

\section{REFERENCES}

1. Goldwasser RS, Lobo MSC, Arruda EF, Angelo SA, Silva JRL, Salles AA, et al. Difficulties in access and estimates of public beds in intensive care units in the state of Rio de Janeiro. Rev Saúde Pública [Internet]. 2016 [cited 2018 Jan 31];50:19. Available from: http://dx.doi. org/10.1590/S1518-8787.2016050005997. English, Portuguese.

2. Lino MM, Calil AM. [Teaching critical/intensive care in nursing education: a moment of reflection]. Rev. Esc Enferm USP [Internet]. 2008 [cited 2016 May 31];42(4):777-83. Available from: http://www.scielo.br/pdf/reeusp/v42n4/en_v42n4a21.pdf . Portuguese.

3. Felippe TDG, Ramos RS, Gomes AMT, Barreto VPM, Oliveira OVS. A representação social dos enfermeiros sobre pacientes críticos no contexto da clínica médica. Rev Cuidarte. 2012;3(1):1-9.

4. Saraiva EL, Sousa CS. Pacientes críticos na unidade de recuperação pós-anestésica: revisão integrativa. Rev SOBECC. 2015;20(2):104-112.

5. Zandomenighi, RC, Mouro DL, Oliveira CA, Martins EAP. Cuidados intensivos em um serviço hospitalar de emergência: desafios para os enfermeiros. Rev Min Enferm. 2014;18(2):404-414.

6. Agência Nacional de Vigilância Sanitária (ANVISA). Consulta Pública n. 21, de 27 de abril de 2006. Regulamento técnico para funcionamento de unidades de terapia intensiva e unidades de cuidados intermediários [Internet]. Diário Oficial da União: República Federativa do Brasil; 2006 [cited 2018 Sep 08]. Mar 28, Seção 1: p. 109. Available from: http://www4.anvisa.gov.br/base/visadoc/CP/CP\%5B14558-1-0\%5D.PDF

7. Viana RAPP, Vargas MAO, Carmagnani MIS, Tanaka LH, Luz KR, Schmitt PH. Profile of an intensive care nurse in different regions of Brazil. Texto Contexto-Enferm [Internet]. 2014 [cited 2016 May 31];23(1):151-159. Available from: http://dx.doi.org/10.1590/S010407072014000100018. English, Portuguese.

8. Castro MCN, Dell'Acqua MCQ, Unger IC, Cyrino CMS, Almeida PMV. Severity and workload of nursing with patients seeking admission to an 
intensive care unit. Esc Anna Nery [Internet]. 2018 [cited 2018 Mar 31];22(1):e20170167. Available from: http://dx.doi.org/10.1590/21779465-ean-2017-0167. English, Portuguese.

9. Benner P. From novice to expert: excellent and power in clinical nursing practice. California (US): Addison Wesley; 1984.

10. Welding NM. Creating a nursing residency: decrease turnover and increase clinical competence. Medsurg Nurs [Internet]. 2011 [cited 2016 May 31];20(1):37-40. Available from: https://www.amsn.org/sites/default/files/documents/practice-resources/healthy-work-environment/ resources/MSNJ_Welding_20_01.pdf

11. Muldowney Y, McKee G. Nurses new to intensive care: perceptions of their clinical learning environment. Nurs Crit Care. 2011;16(4):201-9.

12. Camelo SHH, Silva VLS, Laus AM, Chaves LDP. [Professional profile of nurses working in intensive care units of a teaching hospital]. Ciênc Enferm [Internet]. 2013 [cited 2016 May 31]; 19(3):51-62. Available from: http://dx.doi.org/10.4067/S0717-95532013000300006. Portuguese.

13. Silva RC, Ferreira MA, Apostolidis, T. Intensive care nurses' practice related to experience and shift worked. Intensive Crit Care Nurs. 2016;34:51-58.

14. Jodelet $D$ editor. Représentations sociales. Chapter 1: Representações sociais: um domínio em expansão. Tarso Bonilha Mazzotti translator. Rio de Janeiro: EdUERJ; 2001. p. 17-44.

15. Fontanella BJB, Luchesi BM, Saidel MGB, Ricas J, Turato ER, Melo DG. [Sampling in qualitative research: a proposal for procedures to detect theoretical saturation]. Cad Saúde Pública [Internet]. 2011 [citado 2016 May 31];27(2):389-394. Available from: http://dx.doi.org/10.1590/ S0102-311X2011000200020. Portuguese.

16. Azevedo DM, Miranda FAN. [The social representations theory and Alceste: theorical-methodological contribution in qualitative research] Saúde Transf Soc [Internet]. 2012 [citado 2016 May 31];3(4):04-10. Disponível em: http://www.redalyc.org/articulo.oa?id=265324588003 Portuguese.

17. Arruda A, Pombo-de-Barros CF. Afetos e representações Sociais: contribuições de um diálogo transdisciplinar. Psic Teor Pesq. 2010;26(2):351-60.

18. Ortega MCB, Cecagno D, Llor MAS, Siqueira HCH, Montesinos MJL, Soler LM. Academic training of nursing professionals and its relevance to the workplace. Rev Lat Am Enfermagem [Internet]. 2015 [cited 2016 May 31];23(3):404-10. Available from: http://dx.doi.org/10.1590/01041169.0432.2569. English, Portuguese, Spanish.

19. Pimentel TS, Lúcio IML, Oliveira KCPN, Bastos MLA, Santos EA. Working process of nurses of intensive care units: challenges of academic training. Rev enferm UFPE on line [Internet]. 2013 [cited 2016 May 31];7(10):5915-22. Available from: http://www.revista.ufpe.br/ revistaenfermagem/index.php/revista/article/view/4227/pdf_3610

20. Souza LPS, Silva WSS, Mota ÉC, Santana JM, Siqueira Ld, Oliveira Silva CS, et al. [The challenges of newly-graduated in Nursing in the world of work]. Rev Cubana Enfermer [Internet]. 2015 [cited 2017 Jul 31];30(1):4-18. Available from: http://scielo.sld.cu/pdf/enf/v30n1/enf02114. pdf. Portuguese.

21. Baumberger-Henry M. Registered nurses' perspectives on the new graduate working in the emergency department or critical care unit. J Contin Educ Nurs. 2012;43(7):299-305.

22. Saghafi F, Hardy J, Hillege S. New graduate nurses' experiences of interactions in the critical care unit. Contemp Nurse. 2012;42(1):20-27.

23. Jesus BH, Prado ML, Gomes DC, Canever BP, Spillere LBB. [Job market placement: professional trajectory of nursing graduates]. Esc Anna Nery. [Internet]. 2013 [cited 2017 Jun 20];17(2):336-45. Available from: http://dx.doi.org/10.1590/S1414-81452013000200019. Portuguese.

24. Lima GPV, Lima GPV, Pereira ADLF, Guida NFB, Progianti JM, Araújo CLF, et al. Expectations, motivations and perceptions of nurses on the nurse-midwifery specialization course in the residence modality. Esc Anna Nery [Internet]. 2015 [cited 2017 Jun 20];19(4):593-599. Available from: http://dx.doi.org/10.5935/1414-8145.20150079. English, Portuguese.

25. Lakanmaa R, Suominen T, Pertilla J, Ritmala-Castrèn M, Vahlberg T, Leino-Kilpi H. Graduating nursing students' basic competence in intensive and critical care nursing. J Clin Nurs. 2014;23(5-6): 645-653. 